\title{
The US trade dispute: blunt offense or rational strategy?
}

January 11, 2019

Michael Hübler ${ }^{1}$, Axel Herdecke²

\begin{abstract}
This article evaluates the recent protectionist US trade policy and the retaliation of the EU and China. The article employs a New Quantitative Trade Theory model and an Armington model for comparison. The simulation results show that US car tariffs are a credible threat to the EU, but the steel and aluminum tariffs are not. China suffers considerably from the US tariffs, especially the extended, tightened tariffs that have been announced. The retaliation measures of the EU and China, however, do not cause US welfare losses compared to the situation without such a trade policy.
\end{abstract}

Keywords: Trade policy, trade war, numerical model, USA, EU, China

JEL classifications: F11, F17, F42

\footnotetext{
${ }^{1}$ Corresponding author. Email: huebler@iuw.uni-hannover.de, phone: +49-511-762-19569, fax: +49-511-762-2667. Leibniz University Hannover, Institute for Environmental Economics and World Trade, Königsworther Platz 1, 30167 Hannover, Germany.

${ }^{2}$ Leibniz University Hannover, Germany.
} 


\section{Introduction}

The new protectionist policy wave initiated by the US Trump administration has been a dominant issue in recent international policy debates. Having aborted the Transatlantic Trade and Investment Partnership (TTIP) and the Transpacific Partnership (TPP), the US Trump administration has raised tariffs on steel and aluminum products and announced tariffs on European cars. Meanwhile, the trade dispute between the USA and China was on the verge of escalation, not only because of the US tariffs implemented on 24 September 2018 and the Chinese retaliation tariffs but also because of the announcement of increased tariff rates on a wide range of Chinese goods starting in 2019. When President Donald Trump and President Xi Jinping agreed to refrain from further tariffs during the next 90 days at the 2018 G20 Buenos Aires summit, the stock-market prices recovered. Shortly thereafter, German car producer executives went to the White House to bargain over the announced tariffs on cars.

Because of the novelty of this dispute, policy assessments are rare. The policy (discussion) paper of Felbermayr \& Steininger (2018) assesses the US-EU trade policy dispute with a focus on Austria by applying a statistical general equilibrium model. The paper finds that the trade dispute, particularly the retaliation measures, hurt all trading partners and the entire world economy. The following article extends the analysis by taking the newest policy implementations and announcements into account and by deploying two global general equilibrium models to test the robustness of the simulation results across different model types. This article focuses on macroeconomic welfare effects.

To this end, Section 2 introduces the underlying models, and Section 3 introduces the trade policy scenarios under study. Section 4 discusses the simulation results, and Section 5 concludes with policy implications.

\section{Models}

The Eaton-Kortum model (EKM) follows Pothen \& Hübler (2018), which is based on the Ricardian New Trade Theory of Eaton \& Kortum (2002). It allows the simulation of a TTIP scenario with reductions in nontariff trade barriers based on a structural estimation (see Pothen \& Hübler, 2018). It represents several core EU countries in the GTAP 9 baseline year 2011 and goes beyond GTAP by explicitly representing regions within Germany. It features 19 regions and 18 sectors.

The Armington model (ARM) follows Hübler \& Löschel (2013) and Böhringer et al. (2009), which are based on the standard Armington (1969) specification. Whereas the ARM represents the EU in its

\footnotetext{
${ }^{3}$ Global Trade Analysis Project.
} 
entirety, it goes beyond GTAP by explicitly representing the sectors "manufacturing of iron and steel" and "aluminum", which are particularly targeted by the US tariffs. Furthermore, the model is extrapolated to the year 2020 by expanding the world economy according to EU (2011) (see Hübler \& Löschel, 2013). The ARM features 13 regions and 24 sectors.

\section{Scenarios}

Table 1 details the twelve trade policy scenarios. The tariff rates have been computed by reviewing the available policy information (which, in some cases, is very detailed and product-specific) and transferring it into weighted average tariff rates for the model sectors.

Scenarios 1 and 2 (Free-Trade and TTIP), provide comparative scenarios showing the potential gains of worldwide and transatlantic trade liberalization (see Pothen \& Hübler, 2018). Scenarios 3 to 5 describe the implemented US tariffs on steel and aluminum (US-Steel) and the EU's (US-Steel+Re-EU) and China's (US-Steel+Re-CH) retaliation tariffs. Scenario 4 mimics the threat of US tariffs against EU car producers (US-EU-Cars).

Scenarios 7 and 8 introduce US tariffs against machinery imports from China (US-CH-Mac) and China's retaliation (US- $\mathrm{CH}-\mathrm{Mac}+\mathrm{Re}-\mathrm{CH}$ ). Scenarios 9 and 10 add tariffs on various goods imported from China by the US (US-CH-Mac10) to the tariffs of scenario 7 and add China's retaliation (US-CH-Mac10+Re$\mathrm{CH}$ ) to the tariffs of scenario 8. Scenarios 11 and 12 repeat scenarios 9 and 10 with increased tariff rates on various goods (US-CH-Mac25 and US- $\mathrm{CH}-\mathrm{Mac} 25+\mathrm{Re}-\mathrm{CH}$ ). Scenario 11 also approximates a scenario with a tariff of $10 \%$ on virtually all US imports from China, which was announced in September 2018, as another threat scenario.

- Table 1 about here -

\section{Results}

Table 2 reports model region-specific welfare effects of the trade policy scenarios using the EKM. Table 3 reports those using the ARM.

- Table 2 about here -

- Table 3 about here - 
Economic significance: Under the comparative scenarios, in some regions, the welfare effects of Free-Trade exceed 3\% and those of TTIP exceed $0.3 \%$. Under the US trade policy scenarios, in the EKM representing the year 2011, the welfare effects are relatively small overall (clearly below $0.1 \%$ in most cases, but almost $0.4 \%$ in China under US-CH-Mac25/+Re-CH). In the ARM representing the year 2020 with an extended size of the world economy, the effects become an order of magnitude larger (almost $4.8 \%$ in China under US-CH-Mac25). The welfare effects on the USA are overall small, particularly in the ARM in Table 3, where the USA's small welfare losses are rounded to zero. Although the results for the USA in the ARM seem to underestimate the true effects, the small effects are in accordance with the arguments of some policy makers (such as the US Secretary of Commerce, Wilbur Ross) that due to its sheer size, the USA is hardly susceptible to trade policy impacts. In stark contrast to the small effects on the USA, China is considerably more affected (positively or negatively) by trade policy $(+2.5 \%$ under Free-Trade but -1.7 to $-4.8 \%$ when the USA targets tariffs at China). Overall, the magnitudes of the welfare effects are similar to the GDP effects estimated by Felbermayr \& Steininger (2018).

Free trade \& the TTIP: In the EKM, the USA gains more from Free-Trade $(0.2 \%)$ or TTIP $(0.1 \%)$ than from any protectionist (tariff) policy. The gains from TTIP in the USA and the EU countries in the EKM are not visible in the ARM, which points to the relevance of taking nontariff barriers into account. Other world regions, including China, lose under TTIP due to trade creation within the US-EU free trade area.

US steel, aluminum \& car tariffs: While the USA slightly gains from these policies (approximately $0.05 \%$ in the EKM) in accordance with Felbermayr \& Steininger (2018), the effects on the EU are mixed. The US car tariffs clearly cause welfare losses across the entire EU $(0.04 \%)$ and its member regions (e.g., $0.08 \%$ in Lower Saxony, where Volkswagen has its headquarters). Whereas the US steel and aluminum tariffs make the entire EU slightly worse off, Lower Saxony and the rest of Germany slightly gain, presumably because their steel (products) imports from the world market become cheaper. Whereas in the ARM, the EU's retaliation for the US aluminum and steel tariffs turns the EU loss into a gain, in the EKM, the beneficiaries of the US tariffs within the EU also win while the sufferers lose. Although China gains slightly from the US steel and aluminum tariffs, it is hardly affected in the ARM. In both models, China gains from its own retaliation as well as from that of the EU.

US tariffs targeting China: In both models, the US tariffs cause substantial Chinese welfare losses (increasing from US-CH-Mac over US-CH-Mac10 to US-CH-Mac25), while China's retaliation mitigates its losses. In the EKM, China's retaliation eliminates the USA's trade policy gains (exceeding $0.07 \%$ under US$\mathrm{CH}$-Mac25). The effect of the US-China trade dispute on other world regions, including the EU, is mixed across models and regions. For example, in the EKM, the EU members slightly gain from the dispute in 
most cases, with larger gains in Germany but lower gains in France, the UK and Italy without China's retaliation. Because Canada and Mexico are major trading partners of the USA, they benefit from the USChina trade dispute via trade diversion.

\section{Conclusion}

The US car tariffs are a credible threat to the EU and Germany, but the steel and aluminum tariffs are not. The policy effects are heterogeneous within the EU: Germany gains from most US, EU and Chinese protectionist policies except the US car tariffs, whereas France, the UK and Italy suffer from US steel, aluminum and car tariffs. Although specific companies or industries might be strongly affected by the US trade policy, the macroeconomic welfare effects on the EU are small overall. In part of the model simulations, the USA is marginally susceptible to trade policy effects. In all simulations, the EU's retaliation has a small impact on the USA and does not create US losses compared to the situation without such a trade policy. This result contradicts the recommendation by Felbermayr \& Steininger (2018) and SVR (2018) that the EU use retaliation as a credible threat to enforce WTO conformity and free trade.

In contrast, China suffers considerably from US tariffs, especially the announced tightened tariff rates on a variety of Chinese goods. China's retaliation mitigates its welfare losses and can eliminate US gains, though it does not create gains for China or losses in the USA compared to the situation without such a trade policy. Accordingly, the US trade policy appears to be a credible threat against China but a blunt instrument for creating US benefits. Is the US-China trade dispute harmful for the EU? In this respect, the results are mixed across models and EU regions because of complex trade diversion effects, world market price effects and different trade patterns across the various countries.

According to these simulation results, fear or panic on the EU side is unnecessary. Due to the complexity of international trade linkages, some trade policy effects are difficult to predict ex ante; thus, caution is advisable. Harsh criticism of the US trade policy and retaliation measures seem to be primarily symbolic political statements against further protectionist policies rather than powerful instruments with significant macroeconomic relevance.

Notably, the USA could benefit twofold more from the TTIP and threefold more from global trade liberalization following the WTO's agenda than from any protectionist policy. Because the TTIP also makes the EU better off, a renegotiation of the TTIP is more advisable for both sides than bargaining over additional tariffs (for example, on German cars). This recommendation is in accordance with Felbermayr \& Steininger (2018) and SVR (2018).

In the future, ongoing research will be needed to keep track of this rapidly changing policy domain. 


\section{References}

Armington, P. (1969). A theory of demand for products distinguished by place of production. IMF Staff Papers, Washington, DC, USA, vol. 16, 159-178.

Böhringer, C., Löschel, A., Moslener, U. \& Rutherford, T.F. (2009). EU climate policy up to 2020: an economic impact assessment. Energy Economics 31(2), 295-305.

Eaton, J. \& Kortum, S. (2002). Technology, geography, and trade. Econometrica 70 (5), 1741-1779.

EU (2011). Roadmap for moving to a low-carbon economy in 2050. Communication COM/2011/0112 final. European Commission, Brussels, Belgium.

https://eur-lex.europa.eu/legal-content/EN/ALL/? uri=CELEX\%3A52011DC0112 (accessed 12/2018).

Felbermayr, G. \& Steininger, M. (2018). Was kostet der neue US-Protektionismus Österreich und die EU? Wirtschaftspolitisches Zentrum, Analyse Nr. 17, Universität St. Gallen, St. Gallen, Switzerland, Wien, Austria.

Hübler, M. \& Löschel, A. (2013). The EU Decarbonisation Roadmap 2050: what way to walk? Energy Policy 55, 190-207

Pothen, F. \& Hübler, M. (2018). The interaction of climate and trade policy. European Economic Review $107,1-26$.

SVR (2018). Vor wichtigen wirtschaftspolitischen Weichenstellungen. Jahresgutachten 18/19 des Sachverständigenrats zur Begutachtung der gesamtwirtschaftlichen Entwicklung, Wiesbaden, Germany. 
Table 1: Overview of the trade policy scenarios

\begin{tabular}{|c|c|c|c|c|c|}
\hline No. & Scenario name & Tariff rates EKM in \% & Tariff rates ARM in \% & Description & Status/start \\
\hline 1 & Free-Trade & World: all sectors 0.00 & World: all sectors 0.00 & Worldwide zero tariffs & Hypothetical \\
\hline 2 & TTIP & $\begin{array}{l}\text { USA/EU: all sectors } 0.00 \text {, } \\
\text { reduced non-tariff bar. }\end{array}$ & USA/EU: all sectors 0.00 & $\begin{array}{l}\text { Transatlantic Trade and Investment } \\
\text { Partnership of the USA and the EU. }\end{array}$ & Aborted \\
\hline 3 & US-Steel & $\begin{array}{l}\text { USA: iron \& steel } 17.07 \\
\text { manufactures } 0.01, \text { non-fer. } \\
\text { metals } 3.03\end{array}$ & $\begin{array}{l}\text { USA: iron \& steel } 17.10 \\
\quad \text { aluminium } 8.20\end{array}$ & $\begin{array}{l}\text { The USA levy a } 25 \% \text { tariff on steel and a } 10 \% \\
\text { tariff on aluminium products worth approx. US- } \\
\$ 47 \text { bill. imported from all countries except } \\
\text { South Korea. }\end{array}$ & March/June 2018 \\
\hline 4 & US-Steel+Re-EU & $\begin{array}{l}\text { EU: agri. } 1.48 \text {, food } 4.10 \text {, } \\
\text { chemic. } 0.18, \text { manuf. } 0.29 \text {, } \\
\text { iron \& steel } 8.07, \text { non-fer. } \\
\text { metals } 0.91\end{array}$ & $\begin{array}{l}\text { EU: food \& agri. } 2.47 \text {, iron \& } \\
\text { steel } 8.07 \text {, iron \& steel } \\
\text { processed } 13.20 \text {, alu } 8.10 \\
\text { machinery } 0.12, \text { chemic. } \\
0.18 \text {, textiles } 1.34\end{array}$ & $\begin{array}{l}\text { The EU retaliates by levying tariffs of } 25 \% \text { on } \\
\text { iron, steel and aluminium products and various } \\
\text { goods imported from the USA worth over US- } \$ \\
3 \text { bill. such as motorcycles, motor boats and } \\
\text { tobacco. }\end{array}$ & June 2018 \\
\hline 5 & US-Steel+Re-CH & $\begin{array}{l}\text { China: agri. } 1.79 \text {, food } 5.55, \\
\text { iron \& steel } 1.32, \text { non- } \\
\text { fer. metals } 6.40\end{array}$ & $\begin{array}{l}\text { China: food \& agri. } 2.56 \\
\text { iron } \& \text { steel } 1.32 \\
\text { aluminium } 19.67\end{array}$ & $\begin{array}{l}\text { China retaliates by levying tariffs on iron, steel } \\
\text { and aluminium products and various food } \\
\text { products imported from the USA worth US-\$ } 3 \\
\text { bill. }\end{array}$ & April 2018 \\
\hline 6 & US-EU-Cars & USA: manufactures 3.49 & USA: machinery 4.05 & $\begin{array}{l}\text { The USA threaten the EU with a } 20 \% \text { tariff on } \\
\text { automibiles worth US- } \$ 43 \text { bill. }\end{array}$ & Threat \\
\hline 7 & US-CH-Mac & $\begin{array}{l}\text { USA: manufactures } 2.70 \\
\text { (chemicals 0.003) }\end{array}$ & USA: machinery 7.16 & $\begin{array}{l}\text { The USA levy tariffs of } 25 \% \text { on imports from } \\
\text { China, particularly machinery such as electrical } \\
\text { products, worth US- } \$ 50 \text { bill. }\end{array}$ & July 2018 \\
\hline 8 & US-CH-Mac+Re-CH & $\begin{array}{l}\text { China: agri } 22.32, \text { chem. } \\
7.96, \text { food } 17.73, \text { manuf. } \\
10.39 \text {, crude oil } 1.58, \text { non- } \\
\text { ferrous metals } 2.22\end{array}$ & $\begin{array}{c}\text { China: food \& agri. } 19.75 \\
\text { machinery } 13.81 \text {, crude oil } \\
1.58, \text { non-metallic minerals } \\
2.22\end{array}$ & $\begin{array}{l}\text { China retaliates with a tariffs of } 25 \% \text { on } \\
\text { machinery and food/agricultural goods imports } \\
\text { from the USA worth US- } \$ 50 \text { bill. }\end{array}$ & July 2018 \\
\hline 9 & US-CH-Mac10 & $\begin{array}{l}\text { USA: manufactures } 2.70 \\
\text { (chemicals } 0.003 \text { ) } \\
\quad+\text { all sectors } 4 \%\end{array}$ & $\begin{array}{l}\text { USA: machinery } 7.16 \\
\quad+\text { all sectors } 4 \%\end{array}$ & $\begin{array}{l}\text { Additionally to scenario } 7 \text {, the USA levy a tariff } \\
\text { of } 10 \% \text { on imports from China worth US- } \$ 200 \\
\text { bill. covering various goods. }\end{array}$ & September 2018 \\
\hline 10 & US-CH-Mac10+Re-CH & $\begin{array}{l}\text { China: tariffs scenario } 8 \\
\quad+\text { all sectors } 3.46\end{array}$ & $\begin{array}{l}\text { China: tariffs scenario } 8 \\
\quad+\text { all sectors } 3.46\end{array}$ & $\begin{array}{l}\text { Additionally to scenario } 8 \text {, China retaliates with } \\
\text { tariffs of 5-10\% on various goods worth US- } \$ 60 \\
\text { bill. }\end{array}$ & September 2018 \\
\hline 11 & US-CH-Mac25 & $\begin{array}{l}\text { USA: manufactures } 2.70 \\
\text { (chemicals } 0.003 \text { ) } \\
\quad+\text { all sectors } 10 \%\end{array}$ & $\begin{array}{l}\text { USA: machinery } 7.16 \\
\quad+\text { all sectors } 10 \%\end{array}$ & $\begin{array}{l}\text { Additionally to scenario } 7 \text {, the USA levy a tariff } \\
\text { of } 25 \% \text { on imports from China worth US- } \$ 200 \\
\text { bill. covering various goods. }\end{array}$ & January 2019 \\
\hline 12 & US-CH-Mac25+Re-CH & $\begin{array}{l}\text { China: tariffs scenario } 8 \\
\quad+\text { all sectors } 11.54\end{array}$ & $\begin{array}{l}\text { China: tariffs scenario } 8 \\
\quad+\text { all sectors } 11.54\end{array}$ & $\begin{array}{l}\text { Additionally to scenario } 8 \text {, China retaliates with } \\
\text { tariffs of } 25 \% \text { on various goods worth US- } \$ 60 \\
\text { bill. }\end{array}$ & Hypothetical \\
\hline
\end{tabular}

The retaliation scenarios include the original policy and the reaction, e.g., scenario 4 adds the EU's retaliation to the USA's policy of scenario 3. 
Table 2: Eaton-Kortum model (EKM) trade policy scenario results for 2011

Change in welfare relative to no policy in \%

\begin{tabular}{|c|c|c|c|c|c|c|c|c|c|c|c|c|c|c|c|c|c|}
\hline No. & Scenario name & ISA & $\mathrm{CHN}$ & $L S X$ & $R O G$ & FRA & $G B R$ & ITA & EUR & FSU & CAN & MEX & $J P N$ & $K O R^{*}$ & $B R A$ & IND & $O C E$ \\
\hline 1 & Free-Trade & 177 & & 415 & 232 & 276 & .230 & .746 & 736 & -0.399 & & -0.351 & .830 & 3.021 & -0.249 & & 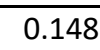 \\
\hline 2 & TTIP & 097 & -0.037 & .126 & 094 & 0.108 & 0.156 & 10 & 30 & 27 & 12 & 25 & 05 & 018 & 03 & 31 & .006 \\
\hline 3 & & & & & & & & & & & & & & & & & \\
\hline 4 & US-Ste & 0.045 & 0.045 & 0.039 & 0.050 & -0.028 & -0.046 & -0.023 & -0.005 & 0.051 & -0.013 & 0.034 & 0.004 & 0.035 & 0.000 & 69 & .001 \\
\hline 5 & $H$ & 049 & & 34 & & & -0.045 & & & & & & & & & & 002 \\
\hline 6 & EU-Cars & 0.042 & 0.007 & -0.076 & 0.070 & -0.020 & -0.012 & -0.017 & -0.034 & -0 . & & 05 & 07 & 16 & 02 & 21 & 0.002 \\
\hline 7 & $a c$ & 24 & & 02 & 00 & & 10 & & & & & 04 & 03 & & & & 001 \\
\hline 8 & $-\mathrm{CH}-\mathrm{Mac}+\mathrm{Re}-\mathrm{CH}$ & .006 & -0. & 005 & 09 & -0.003 & -0.007 & -0 . & & & & 07 & & & 00 & & -0.002 \\
\hline 9 & -CH-Mac10 & 0.056 & -0.2 & 004 & .002 & 0 & 0.028 & 20 & 14 & -0 & & 10 & 08 & 32 & 05 & 44 & -0.001 \\
\hline 10 & $-\mathrm{CH}-\mathrm{Mac} 10+\mathrm{Re}-\mathrm{CH}$ & 0.010 & -0.205 & 0.009 & 0.010 & 0.005 & 0.004 & 0.006 & 0.006 & -0.004 & 0.007 & 0.013 & 0.008 & 0.028 & 0.002 & 12 & 0.000 \\
\hline 11 & US-CH-Mac25 & 0.071 & -0.3 & 0.008 & -0.004 & 0 . & 0.049 & & 25 & -0 & 22 & 18 & & & & 77 & -0.001 \\
\hline 12 & US-CH-Mac25+Re-CH & .001 & -0.377 & 0.014 & 0.014 & 0.012 & 0.013 & 0.014 & 0.012 & -0.007 & 0.014 & 0.021 & 0.013 & 0.045 & 0.006 & 0.028 & 0.003 \\
\hline
\end{tabular}

USA: United States of America, CHN: China, LSX: Lower Saxony (Germany), ROG: rest of Germany, FRA: France, GBR: United Kingdom,

ITA: Italy, EUR: European Union (aggregate), FSU: Former Soviet Union, CAN: Canada, MEX: Mexico, JPN: Japan, KOR: South Korea,

BRA: Brazil, IND: India, OCE: Australia \& Oceania

Table 3: Armington model (ARM) trade policy scenario results for 2020

Change in welfare relative to no policy in \%

\begin{tabular}{|c|c|c|c|c|c|c|c|c|c|c|c|c|}
\hline No. & Scenario name & USA & $\mathrm{CHN}$ & $E U R$ & $R U S$ & CAN & MEX & $J P N$ & SIM & $B R A$ & $I N D$ & $A N Z$ \\
\hline 1 & Free-Trade & 0.000 & 2.457 & 0.328 & -1.291 & -0.377 & -0.772 & 1.892 & 0.913 & 3.123 & -2.166 & 2.629 \\
\hline 2 & TTIP & 0.000 & -0.382 & -0.211 & -0.290 & -0.426 & -0.419 & -0.293 & -0.340 & -0.346 & -0.307 & -0.270 \\
\hline 3 & US-Steel & 0.000 & -0.007 & -0.011 & -0.095 & -0.108 & -0.077 & 0.001 & -0.003 & -0.122 & -0.013 & -0.026 \\
\hline 4 & US-Steel+Re-EU & 0.000 & 0.050 & 0.062 & -0.022 & -0.059 & -0.032 & 0.057 & 0.059 & -0.057 & 0.041 & 0.028 \\
\hline 5 & US-Steel+Re-CH & 0.000 & 0.048 & 0.017 & -0.055 & -0.078 & -0.052 & 0.031 & 0.036 & -0.077 & 0.017 & 0.022 \\
\hline 6 & US-EU-Cars & 0.000 & -0.044 & -0.375 & -0.200 & 0.068 & 0.206 & -0.079 & -0.078 & -0.125 & -0.100 & -0.123 \\
\hline 7 & US-CH-Mac & 0.000 & -1.761 & -0.298 & -0.453 & 0.161 & 0.474 & -0.282 & -0.312 & -0.296 & -0.287 & -0.372 \\
\hline 8 & US-CH-Mac+Re-CH & 0.000 & -1.145 & 0.184 & 0.133 & 0.615 & 0.863 & 0.312 & 0.423 & 0.289 & 0.201 & 0.172 \\
\hline 9 & US-CH-Mac10 & 0.000 & -3.183 & -0.504 & -0.755 & 0.284 & 0.721 & -0.512 & -0.542 & -0.486 & -0.419 & -0.613 \\
\hline 10 & US-CH-Mac10+Re-CH & 0.000 & -2.398 & 0.123 & 0.010 & 0.872 & 1.227 & 0.254 & 0.398 & 0.262 & 0.216 & 0.093 \\
\hline 11 & US-CH-Mac25 & 0.000 & -4.793 & -0.686 & -1.044 & 0.505 & 1.090 & -0.719 & -0.739 & -0.642 & -0.501 & -0.835 \\
\hline 12 & US-CH-Mac25+Re-CH & 0.000 & -3.791 & 0.187 & 0.022 & 1.318 & 1.791 & 0.336 & 0.548 & 0.382 & 0.379 & 0.147 \\
\hline
\end{tabular}

USA: United States of America, CHN: China, EUR: European Union, RUS: Russia, CAN: Canada,

MEX: Mexico, JPN: Japan, SIM: South Korea \& Indonesia \& Malaysia, BRA: Brazil, IND: India,

ANZ: Australia \& New Zealand 